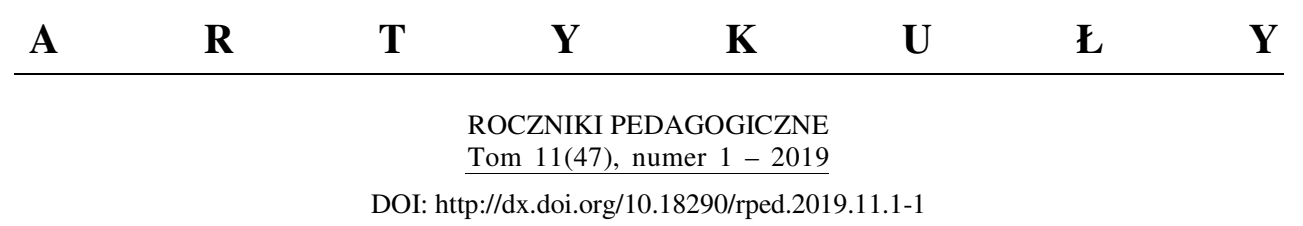

LUCYNA DZIACZKOWSKA

\title{
CZYM JEST PEDAGOGIKA INTEGRALNA?
}

\section{WPROWADZENIE}

Prezentowane niżej rozważania stanowią próbę odpowiedzi na zadane w tytule pytanie. Ujęte w tak nieskomplikowanej, ogólnej postaci, wymaga ono wyodrębnienia przynajmniej dwóch problemów szczegółowych. Po pierwsze należy zapytać: Czym jest w swojej istocie pedagogika integralna? Po drugie: Czym ona jest jako dziedzina kreowana przez pedagogów?

\section{INTEGRALNE ROZUMIENIE CZŁOWIEKA I WYCHOWANIA JAKO ATRYBUT PEDAGOGIKI}

Szukanie odpowiedzi na pierwsze pytanie szczegółowe wypada rozpocząć od przywołania znaczenia łacińskiego przymiotnika występującego w pojęciu „,pedagogika integralna”. Integralis, czyli ,integralny” to - jak wskazuje źródło słownikowe - „nierozdzielnie związany z całością, stanowiący całość; całkowity, nienaruszalny" (Stownik języka polskiego, red. W. Doroszewski, PWN, Warszawa 1980, s. 310). Uwzględniając to rozumienie - z założenia - cała pedagogika jest „integralna”, podejmując zobowiązanie budowania względnie pełnej, całościowej, wiedzy o wychowaniu. Dowodząc autonomii pedagogiki Kazimierz Sośnicki stwierdzał wyraźnie, iż to, czym wyróżnia się ona spośród innych dyscyplin naukowych badających wychowanie, jest poznawanie tego zjawiska w jego

Dr hab. LuCyna Dziaczkowska, prof KUL - Katedra Pedagogiki Porównawczej i Filozofii Wychowania, Instytut Pedagogiki, Katolicki Uniwersytet Lubelski Jana Pawła II; adres do korespondencji: ul. Droga Męczenników Majdanka 70, 20-325 Lublin; e-mail: ldziaczkowska@kul.pl 
złożoności, a nie przez pryzmat fragmentów rzeczywistości o określonym charakterze - np. społecznym czy psychicznym (jak to ma miejsce w socjologii wychowania albo psychologii wychowawczej) (Sośnicki, 1967, s. 26-27).

Powyższą myśl Sośnickiego można wyrazić językiem współczesnej narracji, poszerzając ją o kolejne wątki. Uczynił to m.in. Dariusz Kubinowski, analizując humanistyczny charakter pedagogiki podkreślił, że jej myślenie jest holistyczne, co oznacza, że „ujmuje ona zarówno człowieka, jak i wychowanie całościowo, a zatem w wymiarze biologicznym, społecznym, kulturowym, duchowym itd." (Kubinowski, 2006, s. 178). To z kolei stawia przed reprezentantami tej dyscypliny wymóg „całościowego traktowania pedagogiki”, którego realizacja prowadzi do tego, że ,jest [ona] jednocześnie sztuką i filozofią wychowania, teorią i metodyką kształcenia, refleksją i dyrektywą pedagogiczną, badaniem praktyki edukacyjnej i jego rezultatami itd. Jest to również wymóg komplementarnej adekwatności jej wymiaru ontologicznego, epistemologicznego, metodologicznego i prakseologicznego" (Kubinowski, 2006, s. 178).

Z powyższych rozważań wynika, że integralność jest (a właściwie: powinna być) istotną cechą każdej pedagogiki, ponieważ takie jej uprawianie - uwzględniające złożony charakter wychowania i wielowymiarowość rozwoju człowieka uczestniczącego w tym zjawisku - nie tylko stanowi o jej autonomii, ale ponadto umożliwia oddanie realnego (zatem złożonego, a nie fragmentarycznego, osadzonego zawsze w jakimś kontekście) obrazu rzeczywistości wychowawczej. Wydaje się zatem, że nie jest potrzebne opatrywanie pojęcia pedagogiki dodatkowym określeniem ,integralna”, gdyż zakrawa to na swoistą tautologię. Jaki zatem sens ma ten zabieg? Otóż, wydaje się on zasadny z tego powodu, że zwraca uwagę na najistotniejsze i zarazem trudne do wykonania zobowiązanie pedagogiki, jakim jest właśnie próba uchwycenia realnej złożoności wychowania i jednocześnie troska o pełnię rozwoju uczestniczącego w niej człowieka. Można to wyrazić również tak, posługując się inną tautologią, że chodzi tu o poznanie „najprawdziwszej prawdy" o rzeczywistości wychowawczej. Prawda ta nie jest wcale łatwa do odkrycia i dlatego pedagodzy nieustannie wpadają w pułapki różnych redukcjonizmów. Zadanie, które przed nimi postawiła ich dyscyplina, należy zatem do niemożliwych (w pewnym sensie) do wykonania, a jednocześnie koniecznych do podjęcia. Koniecznych dlatego, że oddalanie się od zadośćuczynienia postulatowi pedagogiki integralnej ostatecznie uderza w pomyślność rozwoju uczestników wychowania, właśnie im grozi niebezpieczeństwem zawężenia/zredukowania pola ich rozwoju, poważnego zakłócenia jego dynamiki. Kreowanie zredukowanych obrazów rzeczywistości wychowawczej czyni wiedzę 
pedagogiczną wyalienowaną z rzeczywistości, którą ma wyjaśniać, stoi na przeszkodzie użyteczności pedagogiki w odniesieniu do realnego człowieka, który nie sprowadza się tylko do swej cielesności, ani też do własnych przeżyć czy intelektu, ale jest dynamicznym podmiotem (niekiedy jednak uprzedmiotowionym $w$ relacjach $z$ potencjalnymi wychowawcami) własnego życia, jak również życia innych i otoczenia.

Pora zadać drugie pytanie: Jak pedagodzy kreują pedagogikę integralną?, czyli: Jak pedagogom udaje się realizować postulaty integralnego ujęcia rzeczywistości wychowawczej i jej uczestników?

\section{HUMANIZM JAKO FUNDAMENT PEDAGOGIKI INTEGRALNEJ}

Wysiłek zmierzający do integralnego ujęcia rzeczywistości wychowawczej z łatwością można dostrzec u początków europejskiej, jeszcze nienaukowej, myśli pedagogicznej. Podstawą dla tworzenia paidei - zrodzonej wówczas przełomowej dla ludzkości propozycji kultury i wychowania społeczeństwa - stał się grecki humanizm. W swojej istocie jest on czymś innym niż indywidualizm. Pochodząc od innego słowa - humanitas - oznaczającego ludzkość, człowieczeństwo, niósł ze sobą dwa zasadnicze znaczenia. Szersze - humanitaryzmu - rozumianego jako troska człowieka o jego dobro oraz węższe i głębsze, szczególnie interesujące pedagoga - „wychowania w człowieku jego właściwego charakteru, prawdziwego człowieczeństwa" (Jaeger, 2001, s. 38).

Źródłem i podstawą tego ,prawdziwego człowieczeństwa” była dla Greków idea człowieka jako „powszechnie ważnego i obowiązującego do naśladowania obrazu gatunku". Przy czym obraz ten nie był sztywnym konstruktem, ale jak pisze Werner Jaeger - „był to żywy kształt, wyrosły jak z ojczystej ziemi ze wspólnoty narodu, podległy w dalszym ciągu wszystkim przemianom historii. Wraz z narodem przeżywał wszystkie jego losy i przechodził wszystkie etapy jego kulturalnego rozwoju" (Jaeger, 2001, s. 37-38). Wskazując w swej paidei na piękno i dobro jako na wartości najwyższe, ku którym należy prowadzić społeczeństwo, Grecy przyjęli, że służące temu wychowanie „musi być procesem podobnym do budowania” - budowania „budowli najwspanialszej”, prawdziwego „,dzieła sztuki”. I jak konkluduje przywoływany tu autor - „Najwspanialszym dziełem sztuki, do stworzenia którego naród ten poczuł się powołanym, okazał się żywy człowiek" (Jaeger, 2001, s. 37). Za dzieło to odpowiedzialnymi wobec wspólnoty społecznej uczyniono poetę, męża stanu i mędrca. W swojej twórczoś- 
ci i działaniach przedstawiali oni wychowanie, które „,nie jest sumą prywatnych starań i zabiegów mających za cel egoistyczne pojmowanie jednostki”. Człowiek jawi się w dziełach najwybitniejszych starożytnych Greków jako związany ze społecznością, jako istota polityczna. Indywidualistyczne ujmowanie człowieka staje się charakterystyczną właściwością myślenia w schyłkowych czasach starożytnej Grecji, w okresie utraty państwowości. Jaeger stwierdza, iż z zapoczątkowanego wówczas sposobu rozumienia człowieka i jego wychowania ,wywodzi się w prostej linii pedagogika czasów nowożytnych" (Jaeger, 2001, s. 40-41).

To ostatnie stwierdzenie jest swoistym oskarżeniem pod adresem współczesnej pedagogiki. Oznacza ono, że wyżej przywoływany, zmarły w 1961 roku, wybitny myśliciel niemiecki, w ,pedagogice czasów nowożytnych” dostrzegał przede wszystkim odejście od założeń starożytnego humanizmu, obranie kursu na kreowanie postaw indywidualistycznych. Takie ukierunkowanie praktyki wychowawczej grozi wyrwaniem jednostki z rzeczywistości kulturowej, redukowaniem jej odniesień społecznych. Wołanie o integralne ujęcie człowieka jest wołaniem nie tylko o integralność ,ja”, ale też o integralność tego ,ja” z innymi. Niesie zatem ze sobą potrzebę odniesień do ludzkiej wspólnoty z jednej strony, a z drugiej potrzebę chronienia jednostki przed jej zawłaszczeniem przez siły społeczne. Wymaga zatem żywej dyskusji na temat treści humanizmu, który będzie stanowił podłoże wiedzy pedagogicznej.

Spór o humanizm i jego kształt rozgorzał szczególnie po drugiej wojnie światowej. Jednym z najbardziej znaczących w nim głosów, uwzględnianym przede wszystkim w twórczości pedagogów personalistycznych, jest propozycja humanizmu integralnego Jacquesa Maritaina. Jako przedstawiciel personalizmu chrześcijańskiego szukał on niewyznaniowych, uniwersalistycznych elementów człowieczeństwa, które mają swoje zakorzenienie w inspiracji chrześcijańskiej. Zmierzał $\mathrm{w}$ ten sposób do budowania filozofii zdatnej „oddziaływać na historię i przyjść z pomocą ludziom" (Maritain, 1981, s. 5).

Zadaniem chrześcijan, podejmujących czynnie trud urzeczywistniania takiej filozofii, byłoby zastąpienie „porządku nieludzkiego”, który godzi w człowieczeństwo ,porządkiem cywilizacji, którą cechować będzie humani zm inte gralny i która będzie cywilizacją chrześcijańską już nie sakralną, ale świecką [...]”. Jak pisze dalej Maritain, wyjaśniając istotę tego humanizmu: „Ten nowy humanizm nic nie ma wspólnego z humanizmem mieszczańskim, jest tym bardziej ludzki, że nie uwielbia człowieka, ale szanuje rzeczywiście potrzeby integralne osoby ludzkiej. Rozumiemy go jako dążenie do realizacji społecznodoczesnej tej troski ewangelicznej o człowieka, która nie może istnieć w sferze 
duchowej jedynie, ale winna się wcielić, oraz ideału wspólnoty braterskiej. Żąda ona od ludzi, by się poświęcali nie dynamice lub imperializmowi rasy, klasy albo narodu, lecz lepszemu życiu braci, dobru konkretnemu społeczności osób ludzkich, pokornej prawdzie wprowadzenia przyjaźni braterskiej w ład społeczny i w struktury życia wspólnego - za cenę trudnego wysiłku oraz pewnego ubóstwa [w przypisie Maritain wyjaśnia, że ma tu na myśli stanu, w którym ludzkie potrzeby są zaspokajane $\mathrm{w}$ taki sposób, że nie dochodzi przy tym do jakiejś wybujałości bądź zbytku w ich zaspokajaniu - przyp. L.D.]. W ten właśnie sposób taki humanizm zdolny jest do wywyższenia człowieka w jedności i w tym jedynie znaczeniu może być h u ma ni z me m he ro i c z n y " (Maritain, 1981, s. 6).

Tłumacząc relacje pomiędzy życiem pojedynczej ludzkiej osoby a życiem wspólnoty filozofowie personalistyczni wskazują na ich ścisły związek. Karol Wojtyła w rozważaniach na ten temat podkreśla nadrzędną rolę „,dobra wspólnego”. Jest ono podstawą stanowienia wspólnotowego „my” i jako takie reprezentuje sobą „większą pełnię wartości” niż „dobro jednostkowe każdego z osobna «ja»”. Nie oznacza to jednak priorytetu tego, co wspólnotowe nad tym, co osobowe w wymiarze indywidualnym. Bowiem, jak dalej pisze Wojtyła: „Nadrzędny charakter dobra wspólnego, większa pełnia wartości, która o nim stanowi, polega ostatecznie na tym, że dobro każdego z podmiotów tej wspólnoty, określającej się jako «my», w owym dobru pełniej się wyraża i pełniej urzeczywistnia. Tak więc poprzez dobro wspólne ludzkie «ja» pełniej i gruntowniej odnajduje siebie właśnie w ludzkim «my»" (Wojtyła, 2000, s. 406). Dobro to jawi się zazwyczaj jako dobro trudne. Dążenie ku niemu wymaga wysiłku ze strony poszczególnych osób, niekiedy nawet postawy poświęcenia. Jest miarą transcendencji ludzkiej osoby. Wojtyła wskazuje przy tym na ,jednorodność podmiotu osobowego i wspólnoty ludzkiej”. Jeśli takiej jednorodności nie ma, jeśli „kształtowanie się różnych «my»” nie jest „wyraźnym refleksem ludzkiego «ja»” i staje się przeciwieństwem „osobowej podmiotowości”, stan taki domaga się korekt ze strony podmiotu-osoby, jej sprzeciwu i twórczego działania. Uzasadnieniem dla potrzeby tego działania jest przyjęcie „tezy o swoistym pierwszeństwie podmiotuosoby względem wspólnoty" (Wojtyła, 2000, s. 406-408). Teza ta stała się istotną dla badaczy rzeczywistości wychowawczej, podążających tropami humanizmu personalistycznego, w Polsce i na świecie. Można ją odczytać w pedagogicznej twórczości Romano Guardiniego, Luigi Giussaniego, Stafana Kunowskiego czy Mariana Nowaka.

Z personalistycznym ujęciem humanizmu, a więc też człowieka i jego relacji do innych, na gruncie polskiej pedagogiki, wyraźnie polemizował Bogdan Sucho- 
dolski. Zarzucił on personalizmowi, że jest on ,próbą obrony człowieka przed światem, jest próbą stworzenia mu własnego królestwa poza rzeczywistością konkretną, codzienną, przeniesienia go w perspektywy religijne, w rozumiany automatycznie świat kultury lub wreszcie w samotność wewnętrzną chronioną przed zgiełkiem życia [...], podstawy personalizmu w jego różnych odmianach mogą być określane jako filozofia człowieka bez świata. Człowiek staje się w niej samoistnym, metafizycznym bytem i ocala siebie samego, jedynego i niepowtarzalnego za cenę odejścia od konkretnej rzeczywistości, w której żyje, porzucenia ryzyka i odpowiedzialności związanych $\mathrm{z}$ miejscem i czasem swego istnienia"(Suchodolski, 1967, s. 109).

W świetle tej krytyki zrozumiałe jest, że sam Suchodolski ,programowo rezygnuje z perspektywy metafizycznej” i nie mówi „o człowieku jako transcendentnym podmiocie" (Jasińska, 1999, 236). Z tej racji jego stanowisko, wbrew jego własnym intencjom, ma znamiona redukcjonizmu. Jak pisze Katarzyna Jasińska: „,[Suchodolski] mówił o duchowości człowieka jako o wyrazie jego kreatywności, o duchowości, która wyraża się w rozumieniu świata, w tworzeniu dzieł kultury. Człowiek przekracza skończoność swego istnienia dzięki temu, że wnosi swój wkład w kulturę, która ma wymiar ponadindywidualny i ponadczasowy - niematerialny, a duchowy właśnie. Człowiek wyrasta ponad naturę, przekracza naturę, wchodząc w świat kultury. W tym sensie przekracza rolę biernego stworzenia. Duchowość człowieka polega na tym, że wyraża się on w pozamaterialnej sferze kultury" (Jasińska, 1999, s. 236).

Suchodolski rezygnuje z perspektywy metafizyczno-religijnej, dostrzegając w niej przede wszystkim źródło alienacji człowieka oraz czynnik zaspokojenia „potrzeb uczuciowo-wyobrażeniowych”. Wskazując na możliwość sprostania tym potrzebom przez sztukę, widzi w wychowawczych działaniach wykorzystujących obok sztuki dziedzinę nauki, instrument laicyzacji sfery światopoglądowej. Założenia te stają się podstawą dla formułowanych przez niego podstaw koncepcji humanizmu tragicznego. Jak sam ją charakteryzuje jest to „koncepcja humanizmu dramatycznego, humanizmu życia i działania wbrew klęskom, wbrew nieszczęściom, przezwyciężania tych przeciwieństw bez apelu do sił nadprzyrodzonych, lecz w sposób apelujący do ludzkiej godności, ryzyka i woli” (Suchodolski, 1967, s. 225-228).

Przyjmując założenia laickiego humanizmu heroicznego, Suchodolski konsekwentnie tworzył swoją wizję pedagogiki integralnej - akcentującej „rolę człowieka w świecie społecznym". W tym świecie lokował problematykę kształtowania osobowości człowieka. Posługiwał się kategorią osobowości jako 
naczelną w rozważaniach o wychowaniu, nie używając kategorii osoby - istotnej dla personalistów. Podkreślał, że „problem osobowości jest dziś problemem społecznego planowania i indywidualnego awansu, problemem konfliktów pomiędzy oportunistycznym przystosowaniem się do warunków życia a śmiałym dążeniem do ich przekształcenia, problemem własnych i cudzych błędów w społecznym działaniu, problemem odpowiedzialności za własne losy i za angażowanie się w sprawy wspólne" (Suchodolski, 1967, s. 110).

Inspirując się twórczością pedagogiczną Bogdana Suchodolskiego, Irena Wojnar sformułowała propozycję rozumienia pedagogiki integralnej jako pedagogiki ogólnej. W świetle tych inspiracji „na miano ogólnej” zasługuje ta pedagogika, która „zajmuje się kształceniem osobowości i ma swoje korzenie w wielkich ideach filozoficznych starożytności greckiej. Jest to pedagogika zorientowana na obronę i rozwój humanistycznego człowieczeństwa, kontynuowana w różnych nurtach myśli europejskiej, odwołujących się do wartości humanistycznych, konkretyzowana w XX już stuleciu przez propozycje pedagogiki kultury i różne nurty pedagogiki personalistycznej" (Wojnar, 2001, s. 40).

Dopełniając obrazu pedagogiki ogólnej jako pedagogiki integralnej, Irena Wojnar wskazuje, że dla osiągnięcia jej statusu ,podstawowe znaczenie ma ujęcie człowieka w perspektywie jego trwałej istoty i zmiennej kondycji, akceptacja wartości, a więc prześwietlającego sens edukacji etosu, a także świadomość znaczenia uwikłań w zmienności świata i konieczność sprostania jego wyzwaniom" (Wojnar, 2001, s. 40). Ponadto współcześnie - jak pisze cytowana autorka - „,naturalna skłonność pedagogiki ogólnej do rozstrzygnięć ponadczasowych, absolutnych, powinna być [...] w sposób istotny wzbogacona o wrażliwość na zmienne kształty czasu, a zwłaszcza na zobowiązania wobec przyszłości” (Wojnar, 2001, s. 40). Z pewną ostrożnością można odczytać zbudowany przez Irenę Wojnar obraz pedagogiki integralnej za próbę pogodzenia propozycji humanizmu Suchodolskiego z humanizmem definiowanym przez personalistów.

W dyskusję o humanizmie jako fundamencie pedagogiki włączają się reprezentanci młodszych pokoleń pedagogów, między innymi Monika JaworskaWitkowska. W swoich pracach: W strone pedagogiki integralnej. Peregrynacje humanistyczne czy Ku kulturowej koncepcji pedagogiki. Fragmenty i ogarnięcie, proponuje ona takie ujęcie człowieka - uczestnika rzeczywistości kulturowej i edukacyjnej - w którym uwaga badacza skupia się na tym, co jest skrywane, niejawne, a także możliwe do uchwycenia w konkrecie - „w drobinie egzystencji”. Dlatego Jaworska-Witkowska w swoich poszukiwaniach badawczych stawia pytanie: „O czym milczy (cały) człowiek?” (Jaworska-Witkowska, 2007, s. 9). 
W jego poznawaniu przyświecają jej jako myśli przewodnie założenia, które określiła w swojej filozoficznej eseistyce Jolanta Brach-Czaina: ,[...] nie chcę myśleć o bycie w ogólności, pozostawiam takie rozważania filozofom, w których nie ma miłości do szczeliny egzystencjalnego konkretu, jaki nas otacza i z którym, jak sądzę, mamy prawo się utożsamiać. Nie chcę też mówić o bycie w całości, ponieważ nie spotykamy go w takiej postaci, tylko wcielony w konkret egzystencjalny: fakty, zjawiska, zdarzenia"(Brach-Czaina, 1992, s. 5). Dbałość o ukazanie takiego konkretu egzystencjalnego wymaga jednocześnie od badacza unikania pułapki fragmentaryzacji, sztucznego abstrahowania z ludzkiej rzeczywistości fragmentów egzystencji, niszczącego realizm w jej poznawaniu (BrachCzaina, 1992, s. 9).

Niezależnie od wskazanych wyżej różnic w definiowaniu humanizmu, leżącego u podłoża poszukiwań pedagogów deklarujących uprawianie pedagogiki integralnej bądź do niej przypisanych, atrybutem jednoczącym odmienne stanowiska jest zobowiązanie badaczy do uchwycenia ,pełnego człowieka”, zarówno w jego wymiarze aktualnym/realnym, jak i potencjalnym/idealnym (służącym do formułowania celów i dążeń oraz służących ich osiąganiu strategii rozwojowych).

\section{METODOLOGIA PEDAGOGIKI INTEGRALNEJ}

Takie rozumienie człowieka domaga się przyjęcia i realizacji określonych warunków postępowania metodologicznego. Można je odnaleźć w pracach pedagogów, którzy w swojej twórczości podjęli trud humanistycznego zorientowania własnych poszukiwań badawczych. Marian Nowak, autor monografii: Podstawy pedagogiki otwartej, w której wyraźnie wybrzmiewają założenia humanizmu integralnego, analizując $\mathrm{w}$ innej swojej pracy naukowe zobowiązania pedagogiki, określił fundamentalne warunki/postulaty jej uprawiania:

- „,nie metodolatria i monizm metodologiczny”, lecz ,integracja wielu podejść", gdyż tego wymaga cel badań pedagogicznych, jakim jest zrozumienie badanej rzeczywistości wychowawczej;

- ukazywanie wychowania w perspektywie jego wielowymiarowości - „mówić o wychowaniu oznacza mówić o wszystkim, ponieważ to, jaki jest człowiek w procesie wychowania, łączy w sobie wszelkie inne fakty i doświadczenia";

- nadanie poszukiwaniom badawczym w pedagogice kierunku (zgodnie z sugestią Wilfreda Carra i Stephena Kemmisa) „dla wychowania”, a nie tylko „nad wychowaniem" (Nowak, 2006, s. 166). 
Ta postulowana w ostatnim warunku zmiana perspektywy badawczej pedagogiki wiąże się z uwrażliwieniem jej reprezentantów na praktyczny wymiar ich aktywności poznawczej. Nie powinna oznaczać ona jednak porzucenia badań „nad wychowaniem". Można tu wręcz sformułować kolejny postulat, by te ostatnie wpisane $\mathrm{w}$ realizację diagnozy rzeczywistości wychowawczej - w imię integralności pedagogiki i jej troski o ,pełnego człowieka” - służyły jako punkt wyjścia w szukaniu optymalizacji działania wychowawczego, ukierunkowanego na wspomaganie rozwoju człowieka, na aktualizację potencjału jego człowieczeństwa. Marian Nowak, korzystając $\mathrm{z}$ inspiracji tkwiących $\mathrm{w}$ niemieckiej pedagogice, przypomina przy tej okazji myśl Wilhelma Flitnera. Niemiecki pedagog ujmował pedagogikę jako naukę hermeneutyczno-praktyczną i głosił postulat uprawiania w jej ramach „refleksji zaangażowanej” (Nowak, 2006, s. 167), szukającej możliwości konstruktywnego dynamizowania rzeczywistości wychowawczej.

Na tle tradycji metodologicznej w pedagogice pojawiają się propozycje nowych, oryginalnych rozwiązań badawczych, żywo dyskutowanych w gremiach pedagogów. Pośród takich propozycji można wymienić drogę wskazaną przez przywoływaną już autorkę - Monikę Jaworską-Witkowską. Przyjęte przez nią zobowiązanie do wnikliwego pójścia w głąb doświadczenia ludzkiego obecnego w „drobinie egzystencji” kazało jej przyjąć kolejne zobowiązanie - zakorzenienia się nie tylko w dziedzinie pedagogiki, ale w „humanistyce integralnej”, w „humanistyce [...] jako całości”. Kazało jej szukać pedagogicznych ,impulsów na styku pedagogiki i filozofii edukacji oraz filozofii kultury, a jednocześnie zawartych w realnych, wpisanych w logikę dzieł (sztuki, literatury) postawach dydaktycznych twórców kultury kształcących adeptów lub współuczestników różnych form sztuki [...]" (Jaworska-Witkowska, 2007, s. 35-36). Co więcej kazało jej również, w imię humanizmu, szukać ,życiodajnych «zaświatów» pedagogicznych” poza dziedzinami humanistyki, na przykład w ekonomii (Jaworska-Witkowska, 2007, s. 13).

Można tu, oczywiście, zapytać o novum takiej drogi poznawczej, bowiem pedagogika, z zasady i konieczności, musi dążyć do współpracy z innymi dziedzinami poznania, a także ze sztuką. Niemniej jednak w swojej twórczości pedagogicznej Jaworska-Witkowska wykorzystuje impulsy tkwiące w sferze literatury pięknej, teatru, eseistyki literackiej i filozoficznej, psychoanalizy na wyjątkowo szeroką skalę. Tak uzasadnia obecność w swoich pedagogicznych poszukiwaniach odniesień do świata artystycznego: „Otwarcie na przestrzeń wszelkiej sztuki jest de facto otwarciem na przestrzeń życia społecznego i możliwością mądrego oglądu teleologii i aksjologii edukacyjnej" (Jaworska-Witkowska, 2007, s. 39). W interpretacji dzieł sztuki ważna jest dla niej ,tradycja psychoanalityczna”, gdyż 
„obiecując spotkanie z tym, co wyparte, a kiedyś «-samowite», «-możliwe», «-ogarnione», «-odgadnione», staje się generatywnym źródłem wiedzy pedagogicznej, szczególnie dydaktycznej, umożliwiającej urzeczywistnianie potencjalności ucznia i intensyfikację zintegrowanej pracy obu półkul mózgowych poprzez aktywną stymulację programami i strategiami rozwijania jego dyspozycji twórczych" (Jaworska-Witkowska, 2007, s. 48). Pytając o zasadność, naukowość czy akademickość wybieranych przez Jaworską-Witkowską obszarów oraz dróg poznawania rzeczywistości wychowawczej, można odpowiedzieć używając argumentacji tej autorki, że ,pedagogika postulowana jako nauka o (pełnym) człowieku nie może sobie pozwolić na zubożenie i dowolne eliminowanie ze swojego dyskursu pojęć i kategorii nawet najgorszych - pilnych - wyczekiwanych" (Jaworska-Witkowska, 2007, s. 54).

Analizując zróżnicowane metodologiczne stanowiska pedagogiki integralnej, można stwierdzić, iż posługuje się ona - z założenia - „metodologią zorientowaną humanistycznie", czyli nastawioną na poznawanie człowieka w bogactwie jego istnienia i działania, wrażliwą na jego przyszłość rozpatrywaną w łączności Z wiedzą o jego przeszłości i teraźniejszości. Z tego właśnie powodu wymaga nieustannego doskonalenia warsztatu metodologicznego, szukania jego adekwatności do dziedziny poznania, jaką jest rzeczywistość wychowawcza. Stąd, poza wykorzystywanymi dotąd metodami, nieustannie jest otwarte pole dla nowych doświadczeń badaczy, dla ich poszukiwań najbardziej optymalnych dróg odkrywania tajemnic ludzkiego uczestnictwa w procesie wychowania.

\section{ZAKOŃCZENIE}

Prezentowane rozważania zaledwie dotykają odpowiedzi na pytanie zadane w tytule. $\mathrm{Z}$ jednej strony odpowiedź na nie wymagała przyjrzenia się pewnemu stanowi idealnemu, założonemu, co wiązało się ze wskazaniem istoty pedagogiki integralnej. Badanie rzeczywistości wychowawczej w jej złożoności oraz holistyczne traktowanie uczestniczącego w niej człowieka, a także ukierunkowanie celu wychowania na ,pełnię” człowieczeństwa, jako zasadnicze rysy owej istoty, określają zadania, ku których realizacji powinni zmierzać pedagodzy przyjmujący zobowiązanie kreowania pedagogiki integralnej. $\mathrm{Z}$ drugiej strony szukanie odpowiedzi na tytułowe pytanie wiązało się z przywołaniem konkretnych przykładów uprawiania tej pedagogiki. Ukazują one różnorodność twórczych rozwiązań badawczych, praktykowanych przez pedagogów integralnych. To zróżnicowanie 
stanowi dla badaczy zachętę do krytycznego wglądu we własną twórczość naukową i do rzeczowej dyskusji nad sposobami realizacji postulatu integralności w pedagogice.

\section{BIBLIOGRAFIA}

Brach-CzAina, J. (1992). Szczeliny istnienia. Warszawa: Państwowy Instytut Wydawniczy.

GiUsSANI, L. (2002). Ryzyko wychowawcze jako tworzenie osobowości i historii. Tłum. A. Surdej. Kielce: Wydawnictwo „Jedność”.

GuARDini, R. (1998). Wiarygodność wychowawcy. Tłum. J. Koźbiał. W: A. RYnio (red.), Pedagogika katolicka. Zagadnienia wybrane (s. 373-381). Stalowa Wola: Oficyna Wydawnicza Fundacji Uniwersyteckiej.

JAEger, W. (2001). Paideia. Formowanie cztowieka greckiego. Tłum. M. Plezia, H. Bednarek. Warszawa: Wydawnictwo Aletheia.

JASIŃSKA, K. (1999). Bogdana Suchodolskiego personalizm laicki? W: F. ADAMSKI (red.), Wychowanie na rozdrożu. Personalistyczna filozofia wychowania (s. 229-243). Kraków: Wydawnictwo Uniwersytetu Jagiellońskiego.

JAWORSKA-WitKowsKa, M. (2009). Ku kulturowej koncepcji pedagogiki. Kraków: Oficyna Wydawnicza „Impuls”.

JAWORSKA-WITKOWSKA, M. (2007). W strone pedagogiki integralnej. Szczecin: Wydawnictwo Naukowe Uniwersytetu Szczecińskiego.

KubINOwSKI, D. (2006). Pedagogiczne myślenie humanistyczne jako kategoria metodologiczna. W: D. KubINOWSKI, M. NowAK (red.), Metodologia pedagogiki zorientowanej humanistycznie (s. 171-187). Kraków: Oficyna Wydawnicza „Impuls”.

Kunowski, S. (1980). Podstawy wspótczesnej pedagogiki. Łódź: Wydawnictwo Salezjańskie.

MARITAIN, J. (1981), Humanizm integralny. Tłum. M. Reutt. Warszawa: Wydawnictwo Krąg.

NowAK, M. (2006). Metodologia pedagogiki między „,naukowością/teoretycznością” a „praktycznością". W: D. Kubinowski, M. Nowak (red.), Metodologia pedagogiki zorientowanej humanistycznie (s. 145-170). Kraków: Oficyna Wydawnicza „Impuls”.

NowaK, M. (1999). Podstawy pedagogiki otwartej. Ujęcie dynamiczne w inspiracji chrześcijańskiej. Lublin: Redakcja Wydawnictw Katolickiego Uniwersytetu Lubelskiego.

SOŚNICKI, K. (1967). Istota i cele wychowania. Warszawa: Wydawnictwo „Nasza Księgarnia”.

SuchodolsKi, B. (1967). Świat człowieka a wychowanie. Warszawa: Książka i Wiedza.

WoJNAR, I. (2001). Jedność i różnorodność pedagogiki zwanej ogólną. W: A. BoGAJ (red.), Rozwój pedagogiki ogólnej. Inspiracje i ograniczenia kulturowe oraz poznawcze (s. 39-47). WarszawaKielce: Wydawnictwo Instytutu Badań Edukacyjnych.

WojtYŁA, K. (2000). Osoba i czyn oraz inne studia antropologiczne. Lublin: Towarzystwo Naukowe Katolickiego Uniwersytetu Lubelskiego. 


\section{CZYM JEST PEDAGOGIKA INTEGRALNA?}

\section{Streszczenie}

Prezentowane rozważania stanowią próbę syntetycznej odpowiedzi na pytanie: Czym jest pedagogika integralna? Czym jest w swojej istocie i czym jest jako dziedzina realnie kreowana przez pedagogów? Z przeprowadzonej analizy wynika, że - w sferze założeń - pokrywa się ona z pedagogiką w ogóle. Przyjęte przez nią niezwykle trudne zadanie badania wychowania w całej jego złożoności oraz jego uczestników w pełni ich jestestwa, generuje potrzebę nieustannego uwrażliwiania pedagogów na unikanie pułapek redukcjonizmu, na przyjęcie humanizmu jako fundamentu prowadzonych poszukiwań. Autorów takich uwrażliwień, którzy jednocześnie zabiegają o ich urzeczywistnienie, można nazwać reprezentantami pedagogiki integralnej. Jest ona kreowana na różne sposoby, niemniej jednak wymaga swoistego postępowania metodologicznego, otwartego na bogactwo stosowanych metod, ciągłe poszerzanie ich katalogu w celu głębokiego poznania procesów wychowawczych i uczestniczących w niej podmiotów.

Słowa kluczowe: pedagogika integralna; humanizm integralny; humanizm tragiczny.

\section{WHAT IS THE INTEGRAL PEDAGOGY?}

\section{S u m m a ry}

The considerations hereby presented are an attempt to synthetically answer the question: What is the integral pedagogy? What is it in its essence and what is it as a field actually created by pedagogues? From the conducted analysis results that, in the sphere of assumptions, it coincides with pedagogy in general. The extremely difficult task of researching education in its complexity as well as its participants fully embracing their being in its integrity, assumed in this field, generates the need to constantly sensitize pedagogues to avoid traps of reductionism, to accept humanism as the foundation of their search. The authors of such sensibilizations, who at the same time strive for their realization, can be called representatives of integral pedagogy. It is created in various ways, but nevertheless requires a specific methodological behavior, open to the richness of the methods used, constantly expanding their range in order to get to know the educational processes and participating entities in to depth.

Key words: integral pedagogy; integral humanism; tragic humanism. 